\title{
PENGARUH KONTRIBUSI PENERIMAAN PAJAK HOTEL DAN PAJAK RESTORAN TERHADAP PENDAPATAN ASLI DAERAH DI WILAYAH KOTA BATAM TAHUN 2012-2014 (Studi Kasus Dinas Pendapatan Asli Daerah di Kota Batam)
}

\section{INFLUENCE OF HOTEL TAX RECEIPT CONTRIBUTION AND RESTAURANT TAX ON REAL REGIONAL INCOME AREA IN BATAM CITY 2012-2014 (A Case Study of Local Revenue Service in Batam City)}

\author{
Aznedra \\ Prodi Akuntansi, Fakultas Ekonomi \\ Universitas Riau Kepulauan, Batam, Indonesia \\ nedrasukses@gmail.com
}

\begin{abstract}
Tujuan dari penelitian ini adalah (1) Untuk mengetahui pengaruh kontribusi penerimaan pajak terhadap pendapatan asli daerah di Kota Batam tahun 2012-2014. (2) Untuk mengetahui pengaruh kontribusi penerimaan pajak terhadap pendapatan asli daerah di wilayah kota Batam tahun 2012-2014. (3) Untuk mengetahui pengaruh kontribusi penerimaan perpajakan pajak hotel dan restoran secara bersama terhadap pendapatan di Kota Batam pada tahun 2012-2014. Jenis penelitian yang digunakan dalam penelitian ini adalah penelitian kuantitatif. Populasi penelitian ini adalah laporan realisasi pajak hotel dan pajak restoran tahun 2012-2014. Teknik pengumpulan data yang digunakan adalah penelitian kepustakaan dan penelitian lapangan. Teknik analisis yang digunakan adalah analisis regresi berganda. Hasil penelitian menunjukkan bahwa (1) pajak hotel variabel parsial namun tidak berpengaruh signifikan terhadap pendapatan. (2) pajak restoran sebagian berpengaruh signifikan terhadap pendapatan dan (3) pajak atas pajak hotel dan restoran berpengaruh secara signifikan terhadap pendapatan,
\end{abstract}

Kata kunci: kontribusi pajak hotel, kontribusi pajak restoran, pendapatan daerah.

\begin{abstract}
The purpose of this research is (1) To know the effect of the contribution of tax revenue to local revenues hotel in the city of Batam years 2012-2014. (2) To determine the influence of the contribution of tax revenue to local revenue restaurants in the city area of Batam years 2012-2014. (3) To determine the influence of the contribution of tax revenue the hotel and restaurant taxes jointly on revenue in the city of Batam in 20122014.This type of research used in this research is quantitative research. The population of this study is the report on the realization of hotel tax and restaurant tax years 2012-2014. Data collection techniques used is a library research and field research. The analysis technique used is multiple regression analysis. The results showed that (1) partial variable hotel tax but not significant effect on revenue. (2) partially restaurant tax significant impact on revenue and (3) the tax on hotel and restaurant taxes jointly significant impact on revenue,
\end{abstract}

Keywords: hotel tax contribution, restaurant tax contribution, local revenue. 


\section{PENDAHULUAN}

Pembangunan daerah perlu dijalankan atau dikembangkan sebagai salah satu upaya penting untuk mewujudkan kehendak otonomi yang luas, nyata dan bertanggung jawab. Dengan otonomi semacam ini diharapkan agar daerah otonom tidak hanya menerima bantuan subsidi dari pusat tetapi dituntut juga untuk menggali potensi dan sumber keuangan baru serta sumber-sumber pendapatan asli daerahnya yang tidak bertentangan dengan kepentingan nasional sesuai dengan peraturan perundang-undangan yang berlaku sehingga pembiayaan kegiatan pemerintah dan pembangunan tersebut dapat mendukung terwujudnya otonomi daerah yang luas dan nyata serta bertanggung jawab.Sumber-sumber pendapatan daerah pada dasarnya dapat dikatagorikan menjadi 2 (dua) kelompok, yaitu kelompok pertama merupakan pendapatan asli daerah yang terdiri dari pajak daerah, retribusi daerah, hasil perusahaan daerah dan lain-lain pendapatan daerah yang sah. Sedangkan kelompok kedua yaitu pendapatan yang merupakan pemberian pemerintah termasuk sumbangan pemerintah pusat dan daerah tingkat I serta sumbangan lainnya yang telah diatur dengan undang-undang. Diantara sumber-sumber pendapatan tersebut, hasil pajak daerah merupakan sumber pendapatan yang sangat pontensial dan memegang peranan yang sangat penting dalam penimgkatan pendapatan asli daerah disamping sumber-sumber pendapatan daerah lainnya.Di dalam UU Nomor 28 tahun 2009 tentang Pajak dan Retribusi Daerah, pajak daerah diartikan sebagai kontribusi wajib pajak kepada daerah yang terutang oleh orang pribadi dan badan yang bersifat memaksa berdasarkan Undang-Undang, dengan tidak mendapatkan imbalan secara langsung dan digunakan untuk keperluan daerah bagi sebesar-besarnya kemakmuran rakyat. Orang atau badan yang dimaksud adalah pembayar pajak yang mempunyai hak dan kewajiban perpajakan sesuai dengan ketentuan peraturan perundang-undangan perpajakan daerah disebut wajib pajak. Sedangkan subjek pajak adalah orang pribadi atau badan yang dapat dikenakan pajak.Pajak daerah terbagi menjadi 2 (dua), yaitu pajak provinsi dan pajak kabupaten atau kota. Pajak Provinsi terdiri dari pajak kendaraan bermotor dan kendaraan di atas air, bea balik nama bermotor dan kendaraan di atas air, pajak bahan bakar kendaraan bermotor, pajak air permukaan, dan pajak rokok. Sedangkan pajak Kabupaten/Kota terdiri dari pajak hotel, pajak restoran, pajak hiburan, pajak reklame, pajak penerangan jalan, pajak mineral bukan logam dan batuan, pajak parkir, pajak air tanah, pajak 
sarang burung walet, pajak bumi dan bangunan pedesaan dan perkotaan, dan bea perolehan hak atas tanah dan bangunan.Salah satu jenis pajak daerah yang ada pada pemerintah kota/kabupaten mempunyai kontribusi yang cukup besar bagi penerimaan asli daerah adalah pajak hotel dan restoran.

Begitu juga dengan kota batam sebagai daerah tingkat II juga memerlukan pembiayaan pembangunan dan pemerintahan dalam pelaksanaan otonomi daerah yang salah satunya diperoleh dengan mengadakan pemungutan pajak hotel dan restoran. Kota batam merupakan daerah yang sedang berkembang serta merupakan pusat pemerintahan dan pembangunan. Sasaran peningkatan sumber pendapatan daerah yang berasal dari pajak hotel dan restoran memiliki dua arti strategis yaitu sebagai sumber pembiayaan pembangunan daerah dan sebagai salah satu komponen dalam melaksanakan otonomi daerah. Salah satu upaya untuk mengoptimalkan penerimaan daerah yaitu dengan cara terus berusaha mencari dan menggali sumber-sumber baru, pendapatan baru dan tidak lupa untuk terus meningkatkan efisiensi sumber daya dan sarana yang terbatas serta meningkatkan efektivitas dari kegiatan yang sudah ada. Upaya peningkatan Pendapatan Asli Daerah harus dilakukan secara terintegrasi dan terkordinasi dari keseluruhan sistem penerimaan daerah. Upaya tersebut efektif apabila diketahui sumber penyebabnya. Oleh sebab itu perlu suatu metode perhitungan untuk melihat seberapa efektif pajak hotel dan restoran yang merupakan salah satu komponen pajak daerah kota batam, memberikan sumbangannya bagi pendapatan asli daerah kota batam. Beberapa fenomena kasus-kasus yang terjadi di kota batam khususnya yang menyangkut dengan pajak daerah yaitu pajak hotel dan pajak restoran yang membuat wajib pajak khawatir untuk membayar pajak dimana dengan adanya peraturan baru yang dibuat oleh Pemerintah yang menyatakan bahwa pegawai negeri sipil dan pegawai swasta tidak diperbolehkan untuk mengadakan acara dalam bentuk seminar, penyuluhan atau kegiatan lainnya di dalam hotel sehingga menyebabkan penerimaan hotel menjadi turun dari tahun sebelumnya. Begitu juga dengan banyaknya restoran yang dibuka maka penerimaan pajak daerah dari pajak restoran seharusnya semakin besar. Oleh karena itu, penulis beranggapan bahwa perlu diadakannya penelitian mengenai hal tersebut pada periode tahun 2012-2014. 


\section{Pengertian Pajak}

Pengertian Pajak secara umum dapat diartikan sebagai iuran atau pungutan yang dilakukan oleh pemerintah dari masyarakat berdasarkan Undang-Undang dan hasilnya digunakan demi pembiayaan pengeluaran umum pemerintah dengan tanpa balas jasa yang ditunjuk secara langsung. Disamping itu ada beberapa Pengertian Pajak menurut UndangUndang dan para ahli dalam bidang perpajakan yaitu sebagai berikut :

Pengertian Pajak menurut Pasal 1, Undang-Undang No.28 Tahun 2007 tentang ketentuan umum dan tata cara perpajakan. "Pajak adalah kontribusi wajib kepada negara yang terhutang oleh orang pribadi atau badan yang bersifat memaksa berdasarkan Undang-Undang dengan tidak mendapatkan imbalan secara langsung dan digunakan untuk keperluan negara bagi sebesar-besarnya dalam kemakmuran rakyat”.

Menurut Prof. Dr. Rochmat Soemitro, SH (dalam buku Perpanjakan edisi Revisi 2011) Pajak adalah iuran rakyat kepada kas Negara berdasarkan undang-undang dengan tidak mendapat jasa timbale (kontrprestasi) yang langsung dapat ditunjukkan dan digunakan untuk membayar pengeluaran rutin. Atau dapat disimpulkan bahwa, pajak memilki unsur- unsur sebagai iuran dari rakyat kepada negara, berdasarkan undang-undang, tanpa jasa timbal atau kontraprestasi dari negara yang secara langsung ditunjukkan, dan digunakan membiayai rumah tangga negara yakni pengeluaran-pengeluaran yang bermanfaat bagi masyarakat luas.

Menurut Prof. Dr. P.J.A Adriani yang dikutip oleh waluyo (2013) Pajak merupakan iuran kepada kasnegara yang dapat dipaksakan yang terhutang oleh yang wajib membayar menurut peraturan-peraturan dengan tidak mendapat prestasi kembali yang langsung dapat ditunjuk dan yang gunanya adalah untuk membiayai pengeluaran-pengeluaran umum berhubungan dengan tugas negara yang menyelenggarakan pemerintahan. Menurut Dr. N.J Feldman yang dikutip oleh siti resmi (2014) Pajak adalah prestasi yang dipaksakan sepihak oleh dan terutang kepada penguasa (menurut norma-norma yang ditetapkan secara umum) tanpa adanya kontraprestasi dan semata-mata digunakan untuk menutup pengeluaranpengeluaran umum.

\section{Fungsi Pajak}

Fungsi pajak seperti yang dikemukakan oleh Mardiasmo (2011) yaitu: 
1. Fungsi budgetair; disebut juga sumber keuangan negara yaitu pajak berfungsi sebagai sumber dana bagi pembiayaan pengeluaran pemerintah.

2. Fungsi regulered (mengatur) yaitu pajak berfungsi sebagai alat untuk mengatur kebijakan pemerintah dibidang sosial dan ekonomi.

\section{Sistem Pemungut Pajak}

Menurut Mardiasmo (2011) sistem pemungutan pajak dibagi 3 yaitu:

$\checkmark$ Official Assesment System yaitu suatu sistem yang memberi kewenangan kepada pemerintah (fiskus) untuk menentukan besarnya pajak yang terutang oleh wajib pajak. Dimana ciri-cirinya adalah wewenang menentukan besarnya pajak yang terutang ada pada fiskus, wajib pajak besifat pasif, dan utang pajak timbul setelah dikeluarkannya surat ketetapan pajak oleh fiskus.

$\checkmark \quad$ Self AssesmentSystem yaitu suatu sistem pemungutan pajak yang memberi wewenang kepada wajib pajak untuk menentukan sendiri besarnya pajak yang terutang. Ciri-cirinya adalah wewenang untuk menentukan besarnya pajak yang terutang ada pada wajib pajak sendiri, wajib pajak aktif mulai dari menghitung, menyetor dan melaporkan sendiri pajak yang terutang, fiskus tidak ikut campur dan hanya mengawasi.

$\checkmark \quad$ With holding system yaitu suatu system pemungutan pajak yang memberi wewenang kepada pihak ketiga (bukan fiskus dan wajib pajak bersangkutan) untuk menentukan besarnya pajak yang terutang oleh wajib pajak. Ciri-cirinya adalah wewenang untuk menentukan besarnya pajak yang terutang ada pada pihak ketiga (pihak selain fiskus dan wajib pajak)

\section{Asas Pemungutan Pajak}

Dalam pemungutan pajak baik yang dikelola pemerintah pusat maupun pemerintah daerah selalu berpedoman pada asas-asas pemungutan pajak (Mardiasmo 2011) yaitu asas tempat tinggal, asas sumber dan asas kebangsaan

\section{a. Asas Tempat tinggal}

Negara mempunyai hak untuk memungut pajak dari seluruh penghasilan wajib pajak berdasarkan tempat tinggal wajib pajak baik penghasilan yang bersumber dari dalam maupun dari luar negeri. Asas ini berlaku untuk wajib pajak dalam negeri. 


\section{b. Asas Sumber}

Asas ini menyatakan bahwa negara berhak mengenakan pajak atas penghasilan yang bersumber di wilayahnya tanpa memperhatikan tempat tinggal wajib pajak.

\section{c. Asas Kebangsaan}

Pengenaan pajak dihubungkan dengan kebangsaan suatu negara. Asas ini diperlakukan kepada setiap orang asing yang bertempat tinggal di Indonesia untuk membayar pajak

\section{Pengelompokkan Pajak}

Menurut Siti Resmi (2014) pengelompokkan pajak dibagi menjadi tiga yaitu:

\section{Menurut Golongannya}

a. Pajak langsung yaitu Pajak yang dipikul sendiri oleh wajib pajak dan tidak dapat dibebankan kepada orang lain. Contohnya pajak penghasilan

b. Pajak tidak langsung yaitu Pajak yang pada akhirnya dapat dibebankan atau dilimpahkan kepada orang lain. Contohnya pajak pertambahan nilai

\section{Menurut Sifatnya}

a. Pajak Subjektif yaitu pajak yang berpangkal pada subjeknya dalam arti memperhatikan keadaan diri wajib pajak. Contohnya pajak penghasilan

b. Pajak Objektif yaitu pajak yang berpangkal pada objeknya tanpa memperhatikan keadaan diri wajib pajak. Contohnya pajak pertambahan nilai dan pajak penjualan atas barang mewah.

\section{Menurut lembaga pemungutnya}

a. Pajak Pusat yaitu pajak yang dipungut oleh pemerintah pusat dan digunakan untuk membiayai rumah tangga negara. Contohnya adalah pajak penghasilan, pajak pertambahan nilai, pajak penjualan atas barang mewah dan bea materai.

b. Pajak Daerah yaitu pajak yang dipungut oleh pemerintah daerah dan digunakan untuk membiayai rumah tangga daerah. Pajak daerah terdiri dari pajak provinsi dan pajak kabupaten.

\section{Pengertian Pajak Daerah}

Menurut undang-undang nomor 28 tahun 2009 tentang pajak dan retribusi daerah , pajak daerah diartikan sebagai kontribusi wajib pajak kepada daerah yang terutang oleh orang pribadi dan badan yang bersifat memaksa berdasarkan undang-undang dengan tidak mendapat kontraprestasi secara langsung dan digunakan untuk keperluan daerah bagi sebesar-besarnya 
kemakmuran rakyat. Adapun jenis pajak yang wewenang pemungutannya diberikan kepada provinsi terdiri dari Pajak kendaraan bermotor, Bea balik nama kendaraan bermotor, pajak bahan bakar kendaraan bermotor, pajak air permukaan dan pajak rokok sedangkan pajak yang dipungut oleh pemerintah kabupaten/kota adalah pajak hotel, pajak restoran, pajak reklame, pajak hiburan, pajak penerangan jalan, pajak mineral bukan logam dan batuan, pajak parkir, pajak air tanah, pajak sarang burung wallet, pajak bumi dan bangunan perkotaan dan pedesaan dan bea peroleha hak atas tanah dan bangunan.

\section{Surat Pemberitahuan Pajak Daerah (SPTPD)}

\section{a. Penyampaian SPTPD}

SPTPD adalah surat yang oleh wajib pajak digunakan untuk melaporkan penghitungan dan/atau pembayaran pajak, objek pajak, dan/atau bukan objek pajak dan/atau harta dan kewajiban sesuai dengan ketentuan perundang-undangan perpajakan daerah. SPTPD harus diisi dengan jelas, benar, lengkap dan ditandatangani oleh wajib pajak atau kuasanya kemudian disampaikan kedinas pelayanan pajak. Penyampaian SPTPD dilakukan paling lama 20 hari setelah berakhir masa pajak. Apabila batas waktu penyampaian SPTPD jatuh pada hari libur maka batas waktu penyampaian SPTPD jatuh pada hari kerja berikutnya. Peyampaian SPTPD dilampiri dengan dokumen yang ditetapkan oleh kepala daerah.

\section{Perpanjangan jangka waktu penyampaian SPTPD}

Kepala daerah yang ditunjuk atas permohonan wajib pajak dengan alasan yang sah dan dapat diterima dapat memperpanjang jangka waktu penyampaian SPTPD paling lama 2 bulan sejak berakhirnya jangka waktu penyampaian SPTPD. Permohonan perpanjangan penyampaian SPTPD diajukan secara tertulis dengan alasan yang jelas kepada kepala daerah atau pejabat yang ditunjuk selambat-lambatnya sebelum berakhirnya batas waktu penyampaian SPTPD dengan melampirkan perhitungan sementara pajak terutang yang harus dibayar.

\section{Pembetulan SPTPD}

Berdasarkan undang-undang no 28 tahun 2007 wajib pajak dengan kemauan sendiri dapat membetulkan surat pemberitahuan yang telah disampaikan dengan menyampaikan pernyataan tertulis dengan syarat Dinas pelayanan pajak belum melakukan tindakan pemeriksaan. Dimana pembetulan surat pemberitahuan harus disampaikan paling lama 2 tahun sebelum 
daluwarsa penetapan. Dalam hal wajib pajak membetulkan sendiri surat pemberitahuan pajak daerah yang mengakibatkan utang pajak menjadi lebih besar kepadanya dikenai sanksi administrasi berupa bunga 2\% per bulan atas jumlah pajak kurang bayar dihitung sejak jatuh tempo pembayaran sampai dengan tanggal pembayaran dan bagian dari bulan dihitung penuh 1 bulan. Jika dinas pelayanan pajak telah melakukan pemeriksaan tetapi belum dilakukan tindakan penyidikan mengenai ketidakbenaran yang dilakukan wajib pajak baik karena kealpaannya sehingga dapat mengakibatkan kerugian negara maka atas perbuatan wajib pajak tersebut tidak akan dilakukan penyidikan apabila wajib pajak dengan kemauan sendiri mengungkapkan ketidakbenaran perbuatan tersebut dengan disertai pelunasan kekurangan pembayaran jumlah pajak yang sebenarnya terutang beserta sanksi administrasi berupa denda sebesar 150\% dari jumlah pajak yang kurang dibayar. Walaupun direktorat jenderal pajak telah melakukan pemeriksaan dengan syarat direktorat jenderal pajak belum menerbitkan surat ketetapan pajak wajib pajak dengan kesadaran sendiri dapat mengungkapkan dalam laporan tersendiri tentang ketidakbenaran pengisian surat pemberitahuan yang telah disampaikan sesuai keadaan yang sebenarnya yang dapat mengakibatkan pajak-pajak yang masih harus dibayar menjadi lebih besar atau lebih kecil, rugi berdasarkan ketentuan perpajakan menjadi lebih kecil atau lebih besar, jumlah harta menjadi lebih besar atau lebih kecil, jumlah modal menjadi lebih besar atau lebih kecil. Pajak yang kurang dibayar yang timbul sebagai akibat dari pengungkapan ketidakbenaran diatas harus dilunasi oleh wajib pajak beserta sanksi administrasi berupa kenaikan sebesar 50\% dari pajak yang kurang dibayar.

\section{Sanksi administrasi}

Apabila SPTPD tidak dilaporkan atau dilaporkan tidak sesuai dengan batas waktu yang telah ditentukan maka wajib pajak dikenakan sanksi administasi berupa denda yang besarnya ditentukan dalam peraturan daerah. Setiap orang yang dengan sengaja tidak menyampaikan SPTPD atau menyampaikan SPTPD tetapi isinya tidak benar atau tidak lengkap dan dapat merugikan negara sehingga dapat menimbulkan kerugian pada pendapatan negara dipidana dengan pidana penjara paling singkat 6 bulan dan paling lama 6 tahun dan denda paling sedikit $2 \mathrm{X}$ jumlah pajak terutang yang tidak/kurang dibayar dan paling banyak 4X jumlah pajak terutang yang tidak/kurang dibayar 


\section{Surat Ketetapan Pajak Daerah}

\section{Surat Ketetapan Pajak Daerah Kurang Bayar (SKPDKB)}

Surat ketetapan pajak yang menentukan besarnya jumlah pokok pajak, jumlah kredit pajak, jumlah kekurangan pembayaran pokok pajak, besarnya sanksi administrasi dan jumlah pajak yang masih harus dibayar.

\section{Surat Ketetapan Pajak Daerah Kurang Bayar Tambahan (SKPDKBT)}

Surat ketetapan pajak yang menentukan tambahan atas jumlah pajak yang telah ditetapkan. Timbulnya ketetapan ini biasanya dikarenakan adanya data baru yang belum terungkap pada saat pemeriksaan sebelumnya pada tahun pajak bersangkutan yang menyebabkan penambahan jumlah pajak yang terutang.

\section{Surat Ketetapan Pajak Daerah Nihil (SKPDN)}

Surat ketetapan pajak yang menentukan jumlah pajak yang terutang sama besarnya dengan jumlah kredit pajak atau pajak tidak terutang dan tidak ada kredit pajak. SKPDN diterbitkan apabila jumlah pajak yang terutang sama besarnya dengan jumlah kredit pajak. Ini dimaksudkan untuk memberikan kepastian hukum bahwa pajak terutang yang dibayar dan dilaporkan oleh wajib pajak telah sesuai ketentuan peraturan daerah tentang pajak daerah yang dimaksud.

\section{Surat Tagihan Pajak (STPD)}

STPD adalah Surat untuk melakukan tagihan pajak atau sanksi administrasi berupa bunga atau denda. STPD diterbitkan baik terhadap wajib pajak yang melakukan kewajiban pajak yang dibayar sendiri maupun wajib pajak yang melaksanakan kewajiban pajak berdasarkan penetapan oleh kepala daerah. Sanksi administrasi berupa denda dikenakan karena tidak dipenuhinya ketentuan formal. Misalnya tidak atau terlambatnya menyampaikan SPTPD

\section{Pendapatan Asli Daerah}

Menurut undang-undang No. 28 Tahun 2009 yaitu sumber keuangan daerah yang digali dari wilayah daerah yang bersangkutan yang terdiri dari hasil pajak daerah, retribusi daerah, hasil pengelolaan kekayaan daerah yang dipisahkan dan lain-lain pendapatan asli daerah yang sah. Sumber-sumber pendapatan asli daerah (PAD) dibagi menjadi 4 jenis pendapatan yaitu:

a. Pajak Daerah 
1. Pajak Provinsi

2. Pajak Kabupaten/Kota

a. Retribusi Daerah

b. Hasil Perusahaan Milik Daerah dan hsil pengelolaan kekayaan daerah yang dipisahkan

c. Lain-lain Pendapatan Daerah (PAD) yang sah yaitu hasil penjualan kekayaan daerah yang tidak dipisahkan, jasa giro, pendapatan bunga, tuntutan ganti rugi, keuntungan selisih nilai tukar rupiah terhadap mata uang asing dan komisi, potongan ataupun bentuk lain sebagai akibat dari penjualan atau pengadaan barang atau jasa oleh daerah

\section{Kontribusi}

Kontribusi digunakan untuk mengetahui sejauh mana pajak daerah memberikan sumbangan dalam penerimaan PAD. Untuk mengetahui kontribusi dilakukan dengan membandingkan pajak daerah periode tertentu dengan penerimaan PAD periode tertentu pula. Klasifikasi kriteria kontribusi persentase:
a) $0,00 \%-10 \% \quad$ : Sangat Kurang
b) $10,00 \%-20 \%$ : Kurang
c) $20,10 \%-30 \%$ : Sedang
d) $30,10 \%-40 \% \quad$ : Cukup Baik
e) $40,10 \%-50 \%$ : Baik
f) Diatas 50\% : Sangat Baik

\section{Pajak Hotel}

\section{a. Pengertian Pajak Hotel}

Didalam peraturan daerah kota batam no 23 tahun 2011 tentang pajak hotel. Pajak hotel adalah pajak atas pelayanan yang disediakan oleh hotel sedangkan yang dimaksud dengan hotel adalah fasilitas penyedia jasa penginapan/peristirahatan termasuk jasa terkait lainnya yang dipungut bayaran yang mencakup juga motel, losmen, gubuk pariwisata, wisma pariwisata, pesangrahan, rumah penginapan, da sejenisnya.

\section{b. Objek dan Bukan Objek Pajak Hotel}

Objek pajak hotel adalah pelayanan yang disediakan oleh hotel dengan pembayaran termasuk jasa penunjang sebagai kelengkapan hotel yang sifatnya memberikan kemudahan, 
kenyamanan, termasuk fasilitas olahraga dan hiburan. Pada pajak hotel ada beberapa hal yang tidak dikenakan pajak dan tidak termasuk dalam objek pajak yaitu:

1. Jasa tempat tinggal asrama yang diselenggarakan oleh pemerintah daerah

2. Jasa sewa apartemen, kondominium dan sejenisnya. Pengecualian tersebut didasarkan pada izin usahanya

3. Jasa tempat tinggal dipusat pendidikan atau kegiatan keagamaan

4. Jasa tempat tinggal dirumah sakit, asrama perawat, panti jompo, panti asuhan, dan panti sosial lainnya yang sejenis

5. Jasa biro perjalanan atau perjalanan wisata yang diselenggarakan oleh hotel yang dapat dimanfaatkan oleh umum

\section{c. Subjek dan Objek Pajak Hotel}

Subjek adalah orang pribadi atau badan yang melakukan pembayaran kepada orang pribadi atau badan yang mengusahakan hotel. Subjek pajak disini maksudnya adalah konsumen yang menikmati dan membayar pelayanan yang diberikan oleh pengusaha hotel. Wajib pajak adalah orang pribadi atau badan yang mengusahakan hotel yang dalam lingkungan perusahaan atau pekerjaannya melakukan usaha dibidang jasa penginapan.

\section{d. Dasar Pengenaan dan Tarif Pajak Hotel}

Dasar pegenaan dan tarif pajak hotel adalah jumlah pembayaran atau yang seharusnya dibayar kepada hotel. Pembayaran adalah jumlah yang diterima sebagai imbalan atas penyerahan jasa sebagai pembayaran kepada pemilik hotel. Tarif pajak hotel ditetapkan paling tinggi sebesar 10\% berdasarkan peraturan daerah kabupaten/kota

Sanksi pidana dalam perpajakan berupa penderitaan atau siksaan dalam hal pelanggaran pajak. Pengenaan sanksi pidana tidak menghilangkan kewenangan untuk menagih pajak yang masih terhutang.

\section{Pajak Restoran}

\section{a. Pengertian Pajak Hotel}

Didalam peraturan daerah kota batam no 23 tahun 2011 tentang pajak restoran. Pajak restoran adalah pajak atas pelayanan yang disediakan oleh restoran sedangkan yang dimaksud dengan restoran adalah fasilitas penyedia makanan dan minuman dengan dipungut bayaran 
yang mencakup rumah makan, cafeteria, kantin, warung, bar, dan sejenisnya termasuk jasa boga/catering.

\section{b. Objek dan Bukan Objek Pajak Hotel}

Objek pajak restoran adalah pelayanan yang disediakan oleh restoran meliputi pelayanan penjualan makanan/minuman yang dikonsumsi oleh pembeli baik dikonsumsi ditempat pelayanan maupun ditempat lain. Dalam undang-undang nomor 28 tahun 2009 disebutkan bahwa yang tidak termasuk objek pajak restoran adalah pelayanan yang disediakan oleh restoran yang nilai penjualannya tidak melebihi batas tertentu yang ditetapkan dengan peraturan daerah Rp 200.000.000,- (Dua ratus juta rupiah)

\section{c. Subjek dan Objek Pajak Restoran}

Subjek adalah orang pribadi atau badan yang membeli makanan/minuman dari restoran. Wajib pajak adalah orang pribadi atau badan yang mendirikan usaha dibidang rumah makan

\section{d. Dasar Pengenaan dan Tarif Pajak Hotel}

Dasar pegenaan dan tarif pajak restoran adalah jumlah pembayaran yang diterima atau yang seharusnya diterima restoran. Pembayaran adalah jumlah yang diterima sebagai imbalan atas penyerahan jasa sebagai pembayaran kepada pemilik restoran. Tarif pajak restoran ditetapkan paling tinggi sebesar 10\% berdasarkan peraturan daerah kabupaten/kota.

\section{Hasil Penelitian terdahulu}

Sebagai tolak ukur dari penelitian ini, penulis menggunakan penelitian yang telah dilakukan sebelumnya. Berikut beberapa hasil penelitian terdahulu yang peneliti pakai sebagai refrensi penelitian saat ini:

1. Bayu Yudha Binta Riawan (2014) melakukan penelitian mengenai kontribusi pajak hotel, pajak restoran dan pajak reklame terhadap PAD Kabupaten Kulonprogo tahun 2011-2013. Studi kasusnya Kabupaten Kulonprogo

2. Vidya Paramitha (2013) melakukan penelitian megenai pengaruh pajak hotel dan pajak restoran terhadap pendapatan asli daerah kota Bandung. Studi kasus kota Bandung.

3. Eka Arief Rustanto (2012) melakukan penelitian mengenai pengaruh pajak hotel dan pajak restoran terhadap pendapatan asli daerah kota Surakarta. Studi kasus pada daerah kota Surakarta 


\section{METODOLOGI}

\section{Objek Penelitian}

Menurut Sugiyono (2010) menyatakan bahwa objek penelitian adalah sarana ilmiah untuk mendapatkan data dengan tujuan dan kegunaan tertentu tentang suatu hal objektif, valid dan realibel tentang suatu hal (variabel tertentu). Dengan demikian yang menjadi objek penelitian dalam penelitian ini adalah pajak hotel dan pajak restoran yang ada dikota batam.

\section{Populasi dan Sampel}

Untuk melakukan penelitian terlebih dahulu harus ditentukan populasi yang diteliti sebagaimana yang dikemukakan oleh sugiyono (2012) mengenai populasi yaitu wilayah generalisasi yang terdiri dari objek/subjek yang mempunyai kuantitas dan karakteristik tertentu yang ditetapkan oleh peneliti untuk dipelajari dan kemudian ditarik kesimpulannya. Berdasarkan pengertian diatas maka dapat disimpulkan bahwa populasi bukan sekedar jumlah yang ada pada objek atau subjek yang dipelajari tetapi meliputi seluruh karakteristik atau sifat yang dimiliki oleh subek atau objek yang diteliti. Adapun yang menjadi populasi dalam penelitian ini yaitu lapran realisasi pajak hotel, pajak restoran dan pendapatan asli daerah (PAD) kota batam tahun 2012-2014.

Defenisi sampel menurut sugiyono (2012) adalah bagian dari jumlah dan karakteristik yang dimiliki oleh populasi tersebut. Pengambilan sampel ini harus dilakukan sedemikian rupa sehingga sampel benar-benar dapat mewakili dan dapat menggambarkan populasi sebenarnya. Teknik penentuan sampel dilakukan dengan teknik sampling jenuh (sensus) yaitu teknik penentuan sampel bila semua anggota populasi digunakan sebagai anggota sampel. Sehingga sampel dalam penelitian ini sama dengan populasinya yaitu laporan realisasi pajak hotel, pajak restoran dan pendapatan asli daerah (PAD) daerah kota batam tahun 2012-2014.

\section{Uji Statistik Deskriptif}

Uji statistic deskriptif digunakan untuk mendeskripsikan atau memberikan gambaran terhadap objek yang diteliti melalui data sampel atau populasi sebagaimana adanya tanpa melakukan analisis dan membuat kesimpulan yang berlaku untuk umum. 


\section{Tabel 1.Hasil Uji Statistik Deskriptif}

\begin{tabular}{lrrrr}
\multicolumn{5}{c}{ Descriptive Statistics } \\
\hline & N & Range & Mean & Std. Deviation \\
\hline PajakHotel & 36 & $5 . \mathrm{E} 9$ & $5.19 \mathrm{E} 9$ & $1.229 \mathrm{E} 9$ \\
PajakRestoran & 36 & $2 . \mathrm{E} 9$ & $2.64 \mathrm{E} 9$ & $6.878 \mathrm{E} 8$ \\
PAD & 36 & $6 . \mathrm{E} 10$ & $5.00 \mathrm{E} 10$ & $1.604 \mathrm{E} 10$ \\
Valid N (listwise) & 36 & & & \\
\hline
\end{tabular}

Sumber: SPSS versi 16.0.0 for Windows, 2016.

\section{Uji Normalitas}

Uji Normalitas data bertujuan untuk menguji apakah dalam sebuah model regresi variabel independen, variabel dependen atau keduanya berdistribusi normal atau tidak. Hasil Uji Normalitas dapat dilihat pada Tabel 4.6 dibawah ini:

Tabel 2. Uji Normalitas Data

\begin{tabular}{|c|c|c|c|c|}
\hline \multicolumn{5}{|c|}{ One-Sample Kolmogorov-Smirnov Test } \\
\hline & & $\begin{array}{c}\text { PajakHot } \\
\text { el }\end{array}$ & $\begin{array}{c}\text { PajakRest } \\
\text { oran }\end{array}$ & PAD \\
\hline $\mathrm{N}$ & & 36 & 36 & 36 \\
\hline \multirow[t]{3}{*}{ Normal Parameters $^{\mathrm{a}}$} & Mean & 5.19E9 & 2.64E9 & $5.00 \mathrm{E} 10$ \\
\hline & Std. & & & \\
\hline & Deviation & $1 . \angle 2 J \mathrm{EJ}$ & $0.0 / 0 \mathrm{OLO}$ & $1.004 \mathrm{~L} 10$ \\
\hline Most Extreme & Absolute & .146 & .114 & .137 \\
\hline \multirow[t]{2}{*}{ Differences } & Positive & .146 & .080 & .137 \\
\hline & Negative & -.076 & -.114 & -.089 \\
\hline \multicolumn{2}{|c|}{ Kolmogorov-Smirnov Z } & .874 & .681 & .819 \\
\hline \multicolumn{2}{|l|}{ Asymp. Sig. (2-tailed) } & .430 & .742 & .513 \\
\hline
\end{tabular}

Sumber: SPSS versi 16.0.0 for Windows, 2016.

Dari Tabel 2. diatas One-Sample Kolmogorov-Smirnov Test dapat dilihat bahwa data berdistribusi normal karena hasil Asymp. Sig variabel independen maupun dependen lebih besar dari 0,05 


\section{Hasil Uji Asumsi Klasik}

\section{Uji Normalitas Regresi}

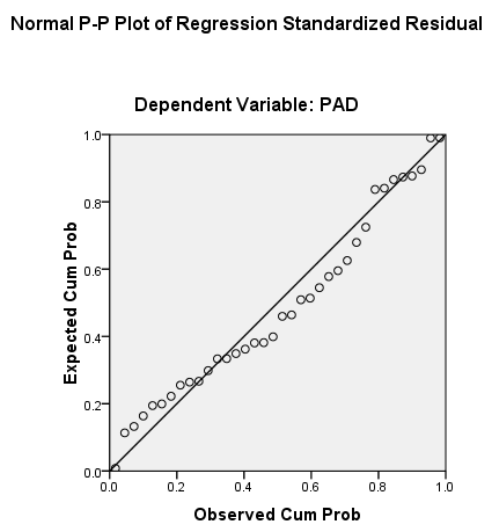

\section{Gambar 1. Uji P-Plot}

Tampak dari gambar 1. grafik normal plot dapat disimpulkan bahwa grafik normal plot terlihat titik-titik menyebar disekitar garis diagonal serta penyebarannya mengikuti dan mendekati garis diagonal. Ini menunjukkan bahwa model regresi layak dipakai karena memenuhi asumsi normalitas.

\section{Uji Multikolineritas}

Uji Multikolineritas bertujuan menguji apakah model regresi ditemukan adanya kolineritas antar variabel bebas. Model regersi yang baik harusnya tidak terjadi korelasi diantara variabel bebas. Jika variabel-variabel ini saling berkorelasi maka variabel-variabel ini tidak orthogonal. Variabel orthogonal adalah variabel independen yang nilai korelasi antar sesama variabel independen sama dengan nol. Uji multikolineritas dapat dihitung dengan rumus (Gujarati 2003) sebagai berikut:

$$
\mathrm{VIF}=\frac{1}{\left(1-r_{\mathrm{xy}}^{2}\right)}
$$

Dimana:

VIF $\quad=\quad$ Variance Inflation Factor

rxy $\quad=\quad$ Besarnya korelasi antara variabel $\mathrm{x}$ dengan variabel $\mathrm{y}$ 
Tabel 3. Uji Multikolineritas

\begin{tabular}{llcc}
\multicolumn{4}{c}{ Coefficients $^{\mathbf{a}}$} \\
\hline & & \multicolumn{2}{c}{ Collinearity Statistics } \\
\cline { 3 - 4 } Model & & Tolerance & VIF \\
\hline 1 & PajakHotel & .563 & 1.776 \\
& PajakRestoran & .563 & 1.776 \\
\hline
\end{tabular}

a. Dependent Variable: PAD

Sumber: SPSS versi 16.0.0 for Windows, 2016.

Hasil uji multikolinieritas dapat dilihat pada tabel coefficients. Berdasarkan tabel 3. diperoleh hasil bahwa VIF untuk variabel independen yang berada dibawah 10 dan nilai tolerance variabel independen yang besaran tolerance $>0,1$ sehingga dapat disimpulkan bahwa tidak terdapat multikolinearitas antar variabel bebas.

\section{Uji Heteroskedastisitas}

Heteroskedastisitas adalah keadaan dimana terjadinya ketidak samaan varian dari residual pada model regresi. Model regresi yang baik mensyaratkan tidak adanya masalah heteroskedastisitas. Uji Heteroskedastisitas dapat dilihat dengan grafik plot (scatterplot) dimana penyebaran titik-titik yang ditimbulkan terbentuk secara acak tidak membentuk sebuah pola tertentu serta arah penyebarannya berada di atas maupun di bawah angka 0 pada sumbu Y. Dengan demikian tidak terjadi gejala heteroskedastisitas pada regresi ini, sehungga model regresi yang dilakukan layak dipakai (Santoso, 2012) 


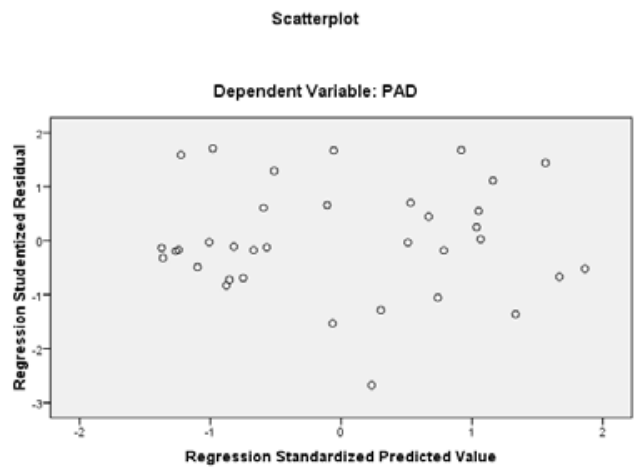

Gambar 2. Uji Scatterplot

Sumber: SPSS versi 16.0.0 for Windows, 2016.

Berdasarkan grafik scatterplot diatas dapat diamati penyebaran titik-titik pada gambar dibawah ini. Dari gambar 4.3 terlihat bahwa titik-titik menyebar secara acak serta tersebar baik di atas maupun di bawah angka 0 pada sumbu Y, sehingga dapat disimpulkan bahwa tidak terjadi heteroskedastisitas pada model regresi.

\section{Uji Autokorelasi}

Uji autokorelasi bertujuan untuk menguji apakah dalam suatu model regresi linear ada korelasi antar anggota sampel yang diurutkan berdasarkan waktu. Penyimpanan asumsi ini biasanya muncul pada observasi yang menggunakan time series. Untuk mendiagnosis adanya autokorelasi dalam suatu model regresi dilakukan melalui pengujian terhadap nilai Durbin-Watson. Dasar pengambilan keputusannya, yaitu jika angka DW diantara -2 sampai 2, berarti tidak ada autokorelasi (Santoso, 2012).

\section{Tabel 4. Uji Auto Korelasi}

\begin{tabular}{|c|c|c|c|c|c|}
\hline \multicolumn{6}{|c|}{ Model Summary } \\
\hline Model & $\mathrm{R}$ & $\begin{array}{c}\mathrm{R} \\
\text { Square }\end{array}$ & \multicolumn{2}{|c|}{$\begin{array}{cc} & \text { Std. Error } \\
\text { Adjusted } & \text { of the } \\
\text { R Square } & \text { Estimate }\end{array}$} & $\begin{array}{l}\text { Durbin- } \\
\text { Watson }\end{array}$ \\
\hline 1 & $.724^{\mathrm{a}}$ & .524 & .478 & $1.140 \mathrm{E} 10$ & 2.102 \\
\hline \multicolumn{6}{|c|}{ a. Predictors: (Constant), Lag_PAD, PajakHotel, PajakRestoran } \\
\hline $\begin{array}{l}\text { b. Depen } \\
\text { Sumbe }\end{array}$ & $\begin{array}{l}\mathrm{nt} \mathrm{V} \\
S P\end{array}$ & $\begin{array}{l}\text { ariable: } \mathrm{P} \\
\text { SS versi }\end{array}$ & $\begin{array}{l}\mathrm{AD} \\
16.0 .0 \mathrm{fo}\end{array}$ & ndows. & \\
\hline
\end{tabular}

Berdasarkan tabel 4.8 diatas dapat dilihat nilai statistik DW adalah 2,102. Dengan melihat tabel durbin Watson $\mathrm{N}=36$ dan $\mathrm{k}=2$ maka dapat diketahui nilai dL sebesar 1.3537 dan dU sebesar 1.5872. 
Dengan membandingkan dengan kriteria yang ada maka nilai DW 2,102 lebih besar dari batas atas (du) 1,5872maka dapat disimpulkan bahwa tidak terjadi autokorelasi positif dan (4-2,102) > 1,5872 menunjukkan bahwa 1,898 > dari 1,5872 sehingga dapat disimpulkan tidak terdapat autokorelasi negative.

\section{Uji Regresi Parsial (Uji T)}

Uji T digunakan untuk mengetahui pengaruh masing-masing variabel independen.

\section{Tabel 5. Analisis Regresi Berganda}

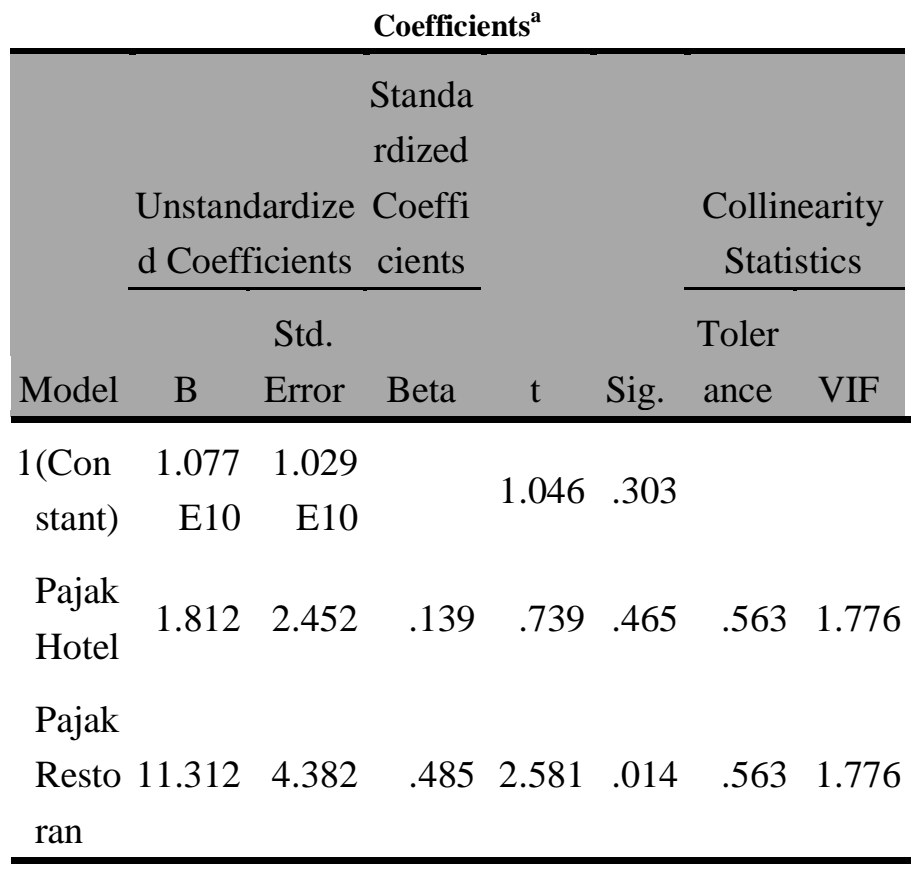

a. Dependent

Variable: PAD

Sumber: SPSS versi 16.0.0 for Windows, 2016.

Berdasarkan Hasil perhitungan dengan menggunakan program SPSS pada table 4.9 diketahui bahwa nilai probabilitas sebesar 0,465 lebih besar dibandingkan taraf signifikansi 5\% atau 0,05 dan nilai table 2,03452 > nilai hitung 0,739 sehingga dapat dikatakan bahwa terdapat pengaruh positif tetapi tidak signifikan Pajak Hotel terhadap Pendapatan asli daerah (PAD) kota batam secara parsial

Berdasarkan Hasil perhitungan dengan menggunakan program SPSS pada table 4.9 diketahui bahwa nilai probabilitas sebesar 0,014 lebih kecil dibandingkan taraf signifikansi 5\% atau 0,05 dan nilai table 2,03452 < nilai t-hitung 2,581 nilai hitung sehingga dapat dikatakan bahwa terdapat pengaruh positif dan signifikan pajak restoran terhadap pendapatan asli daerah (PAD) kota batam secara parsial

\section{.Uji Regrensi Simultan (Uji F)}


Uji Statistik F pada dasarnya menunjukkan apakah semua variabel bebas (independen) yang dimasukkan dalam model mempunyai pengaruh secara bersama-sama terhadap variabel dependen. Berikut disajikan hasil Uji F pada dibawah ini:

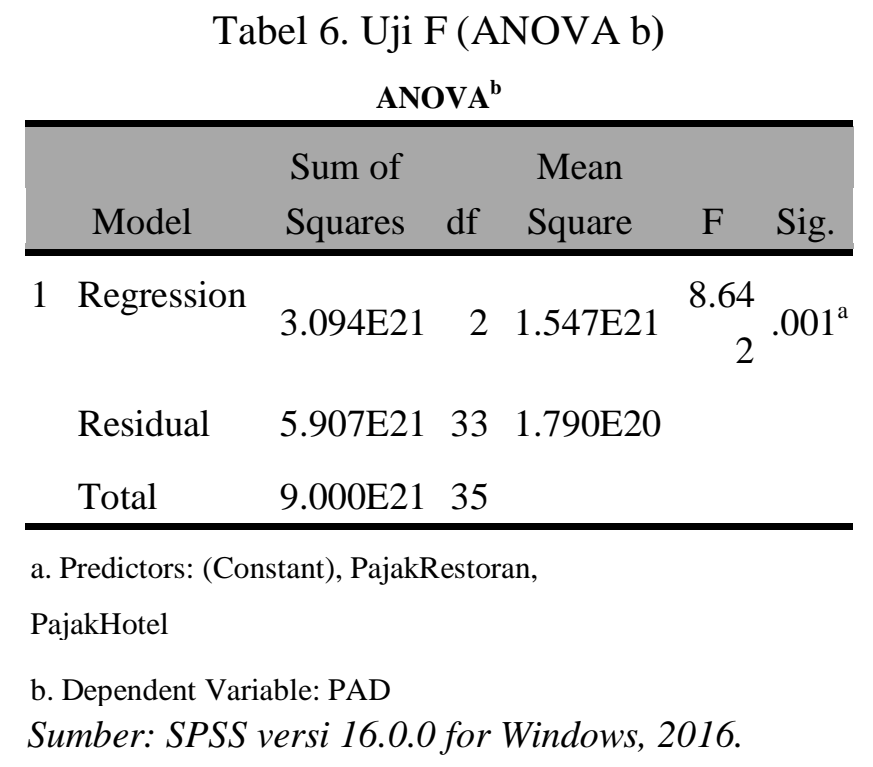

Berdasarkan hasil table 4.10 ANOVA diatas dapat kita lihat bahwa nilai statistic F-hitung sebesar 8,642> 3,28 dari nilai F-tabel dengan nilai siginifikansi sebesar 0,001 ${ }^{\mathrm{a}}<0,05$ yang berarti Pajak Hotel $\left(\mathrm{X}_{1}\right)$ dan Pajak Restoran $\left(\mathrm{X}_{2}\right)$ secara bersama-sama mempunyai pengaruh yang siginifikan terhadap Pendapatan Asli Daerah (Y)

\section{Hasil Uji Koefisien Determinasi $\left(\mathbf{R}^{2}\right)$}

Analisa Koedisien determinasi (uji adjusted R square), untuk mengukur seberapa besar kemampuan variabel independen dapat menjelaskan variabel dependen. Nilai koefisien determinasi adalah antara nol dan satu. Tabel dibawah ini menunjukkan hasil uji koefisien determinasi $\left(\mathrm{R}^{2}\right)$ :

Berdasarkan tabel 4.8 menyatakan bahwa nilai adjusted R-Square sebesar 0,524 artinya besarnya koefisien determinasi sebesar 0,524 hal ini menyatakan bahwa variabel independen menjelaskan variabel dependen sebesar 52,4\%. Sisanya 47,6\% dipengaruhi oleh variabel lain seperti pajak BPHTB (Bea perolehan hak atas tanah dan bangunan), pajak bumi dan bangunan (PBB), pajak penerangan jalan (PPJ), pajak parkir, pajak hiburan dan lain-lain. 


\section{KESIMPULAN}

Berdasarkan hasil analisis dan pembahasan yang telah dilakukan yaitu mengenai pengaruh kontribusi penerimaan pajak hotel dan pajak restoran terhadap pendapatan asli daerah di wilayah kota batam tahun 2012-2014 . Hal ini menunjukkan bahwa:

1. Nilai B pajak hotel pada table coefficients sebesar 1,812 menandakan bahwa Pajak Hotel $\left(\mathrm{X}_{1}\right)$ mempunyai pengaruh positif terhadap Pendapatan Asli Daerah (Y). Nilai siginifikansi sebesar 0,465> 0,05 yang berarti Pajak Hotel $\left(\mathrm{X}_{1}\right)$ mempunyai pengaruh yang tidak siginifikan terhadap Pendapatan Asli Daerah (Y).

2. Nilai B Pajak Restoran pada table coefficients sebesar 11,312 yang menandakan bahwa Pajak Restoran $\left(\mathrm{X}_{2}\right)$ mempunyai pengaruh positif terhadap Pendapatan Asli Daerah (Y). Nilai siginifikansi sebesar 0,014<0,05 yang berarti Pajak Restoran $\left(\mathrm{X}_{2}\right)$ mempunyai pengaruh positif dan siginifikan terhadap Pendapatan Asli Daerah (Y). Hal ini menunjukkan bahwa semakin menjamurnya tempat restoran maka semakin diminati masyarakat yang juga akan meningkatkan pendapatan pajak restoran yang pada akhirnya juga akan meningkatkan pendapatan asli daerah dikota batam

3. Nilai statistic F sebesar 8,642 dengan nilai siginifikansi sebesar 0,001<0,05 yang berartiPajak Hotel $\left(\mathrm{X}_{1}\right)$ dan Pajak Restoran $\left(\mathrm{X}_{2}\right)$ secara bersama-sama mempunyai pengaruh yang siginifikan terhadap Pendapatan Asli Daerah (Y). Hal ini menunjukkan bahwa semakin meningkat penerimaan pajak hotel dan pajak restoran maka semakin meningkatkan penerimaan pendapatan asli daerah (PAD). Sedangkan berdasarkan uji Koefisien determinasi, diketahui pajak hotel dan pajak restoran berpengaruh besar terhadap pendapatan asli daerah (PAD) hal ini dapat dilihat dari persentase hasil uji Determinasi yang menunjukkan angka 52,4\% sedangkan sisanya 47,6\% dipengaruh oleh variabel lain seperti pajak Bea perolehan ha katas tanah dan bangunan (BPHTB), pajak bumi dan bangunan (PBB), pajak parkir, pajak hiburan dan lain-lain.

\section{DAFTAR PUSTAKA}

Aidini Maulida. 2012. "Efektivitas Pengelolaan Pajak Restoran di Dinas Pengelolaan Keuangan Daerah Kota Serang”, Jurnal Akuntansi

Ghozali, Imam. 2006. Aplikasi Analisis Multivariate Dengan Program SPSS.Semarang: Badan Penerbit Undip

------. 2009. Aplikasi Analisis Multivariate Dengan Program SPSS, Edisi Keempat. Semarang: Penerbit Universitas Diponegoro 
DIMENSI, VOL. 6, NO. 2: 235-255

AGUSTUS 2017

ISSN: 2085-9996

Mahmudi. 2010. Analisis Laporan Keuangan Pemerintah Daerah. Yogyakarta: Sekolah Tinggi Ilmu Ekonomi

Mardiasmo. 2011. Perpajakan Edisi Revisi 2011. Yogyakarta: Andi

Memah, Edward W. 2013. "Efektivitas dan Kontribusi Penerimaan Pajak Hotel dan restoran terhadap PAD Kota Manado”, Jurnal EMBA, Vol.1 No.3 Juni 2013

Peraturan Daerah Kota Batam Nomor 23 Tahun 2011 tentang Pajak Hotel.

Peraturan Daerah Kota Batam Nomor 23 Tahun 2011 tentang Pajak Restoran

Resmi, Siti. 2014. Perpajakan. Jakarta: Salemba Empat

Rizki Dewi. 2013. "Pengaruh Pajak Reklame dan Pajak Restoran TerhadapPenerimaan Pajak Daerah Provinsi DKI Jakarta”. Jurnal

Safitri, Ida Orientya Murni, dkk. 2012.“ Efektivitas dan Kontribusi Penerimaan Pajak Hotel dan Pajak Restoran Terhadap Pendapatan Asli Daerah Kota Semaran.” Jurnal

Sanusi. Anwar 2011. Metodologi penelitian bisnis. Jakarta: Salemba Empat

Siagian, P. 2007. Manajemen Sumber Daya Manusia. Jakarta: Bumi Aksara

Siahaan, Marihot Pahala. 2010. Pajak dan Retribusi Daerah. Jakarta: Grafindo

Sugiyono. 2009. Penelitian Pendidikan, Pendekatan Kuantitatif, Kualitatif, dan R\&D.Bandung : Alfabeta

Undang-Undang Nomor 28 Tahun 2009 tentang Pajak dan Retribusi Daerah

Undang-Undang Nomor 32 Tahun 2004 tentang Pemerintah Daerah.

Undang-Undang RI Nomor 28 Tahun 2007 tentang Perubahan Ketiga dari Undang-Undang Dasar Nomor 6 Tahun 1983 tentang Ketentuan Umum dan Tata Cara Perpajakan.

Waluyo. 2013. Perpajakan Indonesia Edisi Kesebelas Buku Satu. Jakarta: Salemba Empat 